\title{
Investigation of the Attitudes of Visual Impairment Individuals on Playing the Games Containing Physical Activity
}

\author{
İbrahim Dalbudak \\ Atabey Vocational School, Isparta University of Applied Sciences, Turkey
}

Copyright $\mathrm{C} 2019$ by authors, all rights reserved. Authors agree that this article remains permanently open access under the terms of the Creative Commons Attribution License 4.0 International License

\begin{abstract}
This study is conducted with the aim of investigating the attitudes of visual impairment individuals on playing the games containing physical activity. The game is a culture. It differs in each culture. The game gives the possibility of free life through these activities, which are found in the structure of the inner world of the individual. It provides the spring of the powers of the individual, and strengthens and develops the human in many ways. It makes life livable and saves it from being monotony and ordinary; our pleasure, our source of happiness and joy, our desire to improve ourselves increase; our relationship with people are better off; increasingly we become like ourselves and part of everything. This study was conducted with a total of 191 visual impairment individuals who had different visual acuity. Volunteering was taken into consideration in participation. An analysis of the attitudes of visual impairment individuals to play games with physical activity according to their gender, disability status, sports branches, marital status, age groups, educational status, income level, and visual acuity. "Playfulness Scale" was used as a data collection tool in the study. The scale consists of 5 sub-dimensions which are the passion for play, risk-taking, social cohesion, game desire, and enjoyment. In this study where analysis of attitudes towards playing games containing physical activity was analyzed, SPSS 22.00 was used which is used in quantitative research methods. Data are summarized by giving percentage and frequency tables. It is seen that the value of the kurtosis and skewness of the variable is -.926 and .095 and these values are between -1 and +1 . Therefore, it can be said that the variable has a normal distribution. In the way, the attitudes of visual impairment individuals towards playing games containing physical activity were not significantly different according to gender, age, sports branch, educational status and visual acuity ( $\mathrm{p}>0.05)$. It is seen that there is no significant difference in the attitudes of visual impairment individuals towards playing games containing physical activity according to their marital
\end{abstract}

status, disability status, and level of income $(p<0,05)$. As a result, the game, the attitudes of visual impairment individuals towards playing games containing physical activity, should not be considered as a recreating activity played by visual impairment individuals. It should not go unnoticed that the game is a real and important tool in human life. The game develops the imagination, creativity, body, and psychology of both children and individuals. It enhances human relations, socialization, cooperation and enjoyment of life and many of the rules, which are hardly taught and should be obeyed can be taught more easily to individuals during play. In short, the game is the easiest way for people with disabilities to be a part of their lives and can freely express themselves, do something during the game, voluntarily play in games, enjoy them, and prove their existence by adhering to rules and events. By forgetting the concept of the disability, enjoying the game, eliminating the stress and the distress of life, it is a piece of those people to hold on to the life.

Keywords Visually-handicapped, Physical Activity, Game, Attitude

\section{Introduction}

The concept of play has been studied for many years by different theories and disciplines (Saracho, 2004). Even though it is not known when the game started and developed, it is a known fact that the game is as old as the most primitive tribes. The first person, in order to gain an advantage in the struggle in nature; attempts to imitate, to fight can be shown as the beginning of the game. At the same time, it was also resulted from the need to adapt to the environment (Hazar, 2000). Huizinga (2006) argues that the game is older than the culture, no matter how much the concept of culture is narrowed, and that culture is born in 
the form of play, and that culture is the game played from the beginning, and that the phenomenon of play is the mediator of cultural transmission. There is no time and place limitation in the game (Georges, 2007). The game has many definitions in the literature. The game "is a voluntary action or activity accompanied by a sense of tension and joy and a 'other being' consciousness of customary life with a purpose within the boundaries of certain time and space in accordance with strictly prescribed rules" (Huizinga, 2006). The play is an activity that allows children and, to a lesser extent, adults to rest in their free time remaining from their daily livelihoods without having to make any production effort or other kinds of services (Hazar, 1996). In general, play is defined as activities that make him happy and benefit him in many ways, whether or not the child is willing to participate in the rules (Yeşilkaya, 2013).

The game is influential on education as it is an effective supporter in learning. It is used as an effective tool in the education process. As emphasized earlier, especially in early childhood education, game is important in the physical, psychological and social development of the child. The personality of the child is shaped by the game, their skills are directed. Human relations, cooperation, honesty, win and lose facts are learned through the game (Yaşar, 2019; Çoban, 2006). In particular, in the development of the child's personal characteristics, teaching through games can be used. Thus, all aspects of the child can be discovered (Hazar, 1996). In short, the game directly affects the whole development of the child. It is a fact that these influences affect the development of the child as a whole, although they are differentiated according to the characteristics of each game (Erdem, 2003). The game is an effective supporter of the learning process (Jordan, 2011).

The game is extremely important for children with disabilities and they need games more. Game, sports and competition activities are the easiest way to rehabilitate and communicate with the community (Ergun et al., 1990). Through sportive actions, game, the morality education, to share a sense of love, to provide a sense of sharing, primitive aggression needs and actions for the environment and methods can be provided and practices can be made (Özoğlu, 1997). The experiences obtained through movements are not an aim in themselves, but a basic tool that is continuous and effective in growth and development. Physical education and sporting activities enable individuals with disabilities not only to control their feelings such as aggression, anger and jealousy, which arise as a natural consequence of their disabilities but the attitude of the society towards them as well (Kinal1, 2003). In the first article of the Declaration on the Rights of the Handicapped Persons, Number 3447, in "Universal Declaration of Human Rights", individuals with disabilities are defined as "the those who cannot do the work they need to do in their personal or social life in a normal person, as a result of any deficiency in their physical or mental abilities". Disability can be defined as "conducting activities limitedly or not fully which can be successfully conducted by a normal person, a result of deficiency in anatomical, physiological or psychological structure and functions and the situation" (Açak et al., 1997). People with disabilities constitute $10 \%$ of the world population (Özer, 2001). This corresponds to approximately 500 million people (Barnes, 1998). In his studies, Hargreaves (2000) reported that this ratio is around $14 \%$ in Turkey. İndividuals with disabilities in Turkey are categorized into four groups as mental, physical, visual and hearing impaired. There are more than 161 million people, who visual impairment in the world among these individuals, 124 million with low vision acuity and 34 million are blind (WHO, 2013). According to Turkey Disability Survey (Turkey Disability Survey, 2002), "visually handicapped" $\mathrm{s}$ constitute 0,60 's $\%$ of the population. Although there are many definitions and classifications related to visual impairment, the rate of loss in vision is based on. According to the accepted description in both international and national literature; "After all possible corrections, if the person's opinion is lower than 20/200, or even less than 20 degrees (despite the field of vision corrective lenses; those people are called blinds". (Özida, 1999; Turnbull et al., 2004; Özyürek, 1995). Low vision is the person who has visual impairment after visual refractive corrections and plan and perform a job visual acuity of which visual acuity is less than 6/18 (20/60) (Ak1 and Kayıhan, 2003).

IBSA has identified three classes in an international competition for partially blind or blind athletes (IBSA, 2006). Each class applies its own sports games for the visually handicapped. These are;

B1: No light perception in either eye up to light perception or an inability to recognize the shape of a hand at any distance or in any direction.

B2: From ability to recognize the shape of a hand up to visual acuity of 20/600 and/or a visual field of less than 5 degrees in the best eye with the best practical eye correction.

B3: From visual acuity above $20 / 600$ and up to visual acuity of 20/200 and/or a visual field of less than 20 degrees and more than 5 degrees in the best eye with the best practical eye correction (IBSA,2006).

Considering the concepts of human rights and equality of opportunity in the context of democracy, it is the most natural rights of handicapped individuals to benefit from sports training or sports games as other normal individuals and equal opportunities should be created in this field (Atay, 1995). Sports or games are the easiest way for the handicapped to communicate with the society physically, psychologically and socially (Akdenk et al. 1997). People participate in sports activities regardless of the disability situation or participate in sports games, move, and exercise to increase the person's desire to live. İndividuals with 
disabilities can solve their loneliness, learn to share their problems with others, socialize, learn to share their problems with others, discipline, learn to control themselves, discover and develop their skills, have positive feelings towards himself, love life, accepting success and failure allows the individual to continue his life (Dalbudak, 2012).

The game is an important event in the lives of people of all ages. For adults; it means entertainment, recreation, leisure activity etc. The game means entertainment, recreation, leisure activity etc. for adults; for the children it means a tool to understand and recognize the world he lives in. For this reason, it should be considered a serious activity, a large part of the time of the child, not a leisure activity. The child thinks through the game and wins with experience. They will have the opportunity to comprehend and explain the properties of substances and their limitations through games. In fact, he learns the relationship between people by way of the game, comprehends. He learns to accept his friends requests or making them easily accept his requests through the conflicts that he has experienced during the game (Şahin, 1993). The game starts from the mother's womb to the end of life. The game is individually important to the people with disability of all ages. For adults with disabilities; it allows them to feel like a healthy individual, to accept their disability, to act independently, to increase their joys of life and, most importantly, to develop their own self-confidence and perspective about life. For children with disabilities, the mobility functions of the individuals with disabilities are developed and rehabilitated. In addition, mental functions also develop and their confidence in them increases. They are provided to keep pace with social life. Children with disabilities through exercises to help develop skills such as good posture, proper walking, jogging and swimming can earn a lot of skills through training with game. In addition, they can strengthen their muscles with physical education programs, and have social and emotional benefits such as self-confidence and self-acceptance. The game is not a recreation but is an activity that individuals of all ages can enjoy the life. The game is an effort that connects the handicapped individuals of all ages to life and adds joy to life (Kınalı 2003; Hazar, 2000; Özer, 2001).

This study is conducted with the aim of investigating the attitudes of visual impairment individuals on playing the games containing physical activity. With this study, it is very important to determine the goals of visually individuals with disabilities regarding their attitudes towards playing games containing physical activity, the development of the game; and the fact that the visually handicapped have independent movement skills and that they are independent of their daily activities.

\section{Materials and Methods}

"Playfulness Scale" in data collection and "Personal Information Form" which was prepared by researchers about demographic features were used, and it has two parts. In the first part, students' personal information form (age, gender, educational status, sports branch, disability situation, the degree of vision, income status, marital status) are included.

In the second part, "the Playfulness Scale", developed by Hazar (2013), consisting of 33 items was used. After the analysis, it was decided to delete 10 items- which are 9, 13, $14,16,22,23,27,28,29,30$. The item number of the scale was reduced to 23. Scale; the game consists of 5 sub-dimensions: the passion for play, risk-taking, social cohesion, game desire, and enjoyment. A 5-point Likert-type scale was used to evaluate the expressions in the scale $(1=$ Strongly Disagree, $2=$ Disagree, $3=$ Undecided, $4=$ Agree, $5=$ Strongly Agree). In order to determine the reliability of the scale, a descriptive factor analysis was applied and Unity in the Game Scale' showed 2-factor order and Cronbach's alpha value was calculated as 0.86 . "In scale development, the alpha coefficient is between 0.60 and 0.79; which is quite reliable (Alpar, 2010)“. Hazar (2015) applied explanatory factor analysis to determine the reliability of the Playfulness Scale on 18-22 and the Cronbach Alpha value was calculated to be 0.85 . As a result of our study, Cronbach's Alpha value of the scale was found as 0.7754 .

\subsection{Analysis of the Data}

Before analyzing the data, analysis assumptions were examined. The data from the lost and incorrect codings were purged and the normality assumption was tested with the skewness and kurtosis value. Then, in the analysis of the data, frequency, mean standard deviation is used; besides, T-test was used for the analysis of gender, disability, marital status, and sports branches; One-way variance (ANOVA) was used in age, education status, and visual acuity. In variance analysis, The Bonferroni method is a widely used multiple comparison tests and does not require the principle of "number of proportion sampling" (Miller, 1969; cited in Kayri, 2009). Therefore, in the case of significant differences, the variance analysis results were compared using the Bonferroni test. The analyzes were tested with SPSS 22 and .05 significance level.

Within the scope of normality tests; Table 1 provides descriptive statistics on the game scores of the participants. It is seen that the value of the kurtosis and skewness of the variable is -.926 and .095 ; and these values are between -1 and +1 . Therefore, it can be said that the variable has a normal distribution. 


\subsection{Findings}

Table 1. Descriptive Statistics on Game Scores

\begin{tabular}{|c|c|c|c|c|c|}
\hline Variable & $\mathbf{N}$ & Average & Standard Devitation & Kurtosis & Skewness \\
\hline Game & 191 & 3.5709 & 0,53403 & -.926 & .095 \\
\hline
\end{tabular}

Table 2. Visual impairment Individuals' Distribution According to Age, Disability Status, Gender, Education Status, Sports Branches, Level of Income, Visual Acuity, Marital Status

\begin{tabular}{|c|c|c|c|}
\hline & & $\mathbf{n}$ & $\%$ \\
\hline \multirow{2}{*}{ Gender } & Male & 128 & 67 \\
\hline & Female & 63 & 33 \\
\hline \multirow{3}{*}{ Age } & Under 18 Age & 39 & 20,4 \\
\hline & 18-30 Age & 101 & 52,9 \\
\hline & Over 30 Age & 51 & 26,7 \\
\hline \multirow{2}{*}{ Marital Status } & Single & 126 & 66 \\
\hline & Married & 65 & 34 \\
\hline \multirow{2}{*}{ Disability Status } & Congenital & 164 & 85,9 \\
\hline & Afterward & 27 & 14,1 \\
\hline \multirow{3}{*}{ Level of Education } & Primary Education & 20 & 10,5 \\
\hline & High School & 87 & 45,5 \\
\hline & University & 84 & 44 \\
\hline \multirow{2}{*}{ Sports Branches } & Individual Sports & 145 & 75,9 \\
\hline & Team Sports & 46 & 24,1 \\
\hline \multirow{3}{*}{ Level of Income } & 1000 & 30 & 15,7 \\
\hline & $1000-2000$ & 157 & 82,2 \\
\hline & 3000 & 4 & 2,1 \\
\hline \multirow{3}{*}{ Visual Acuity } & $\mathrm{B} 1$ & 64 & 33,5 \\
\hline & B2 & 76 & 39,8 \\
\hline & B3 & 51 & 26,7 \\
\hline
\end{tabular}

T-test findings for participants' attitude on playing games according to the gender variable were given in the Table 3.

Table 3. Findings on Scores of Participants' the Attitudes towards Playing The Games According to Gender Variable

\begin{tabular}{|c|c|c|c|c|c|c|c|}
\hline & Gender & $\mathbf{N}$ & Average & Std D. & $t$ & Std D. & $\mathbf{p}$ \\
\hline \multirow{2}{*}{ Game Passion } & Male & 128 & 2,4154 & ,93816 & $-1,230$ & 189 &, 220 \\
\hline & Female & 63 & 2,5899 & ,88992 & & & \\
\hline \multirow{2}{*}{ Risk Taking } & Male & 128 & 3,4313 & ,98090 & 2,845 & 189 &, 005 \\
\hline & Female & 63 & 3,0000 & ,99353 & & & \\
\hline \multirow{2}{*}{ Social Cohesion } & Male & 128 & 4,2917 & 61193 & $-1,981$ & 189 & 049 \\
\hline & Female & 63 & 4,4603 & ,40683 & & & \\
\hline \multirow{2}{*}{ Game desire } & Male & 128 & 4,2676 & ,56487 & 2,385 & 189 &, 018 \\
\hline & Female & 63 & 4,0040 & ,95830 & & & \\
\hline \multirow{2}{*}{ Enjoyment } & Male & 128 & 3,6934 & 83372 & $-2,548$ & 189 &, 012 \\
\hline & Female & 63 & 4,0040 & 69921 & & & \\
\hline \multirow{2}{*}{ Average } & Male & 128 & 3,5697 & 55461 &,- 044 & 189 & ,965 \\
\hline & Female & 63 & 3,5733 & ,49383 & & & \\
\hline
\end{tabular}


When the findings of the participants' attitudes towards game play were examined according to gender, it was determined that there was no significant difference in the attitudes of the participants according to gender $(t(189)=-$, $044, p>.05$ ). Considering the sub-factors of the attitudes towards play, it was found that there is a significant difference in sub-dimensions of risk taking $(\mathrm{t}(189)=2,845$, $\mathrm{p}<.05)$, social cohesion $(\mathrm{t}(189)=-1,981, \mathrm{p}<.05)$, game request $(\mathrm{t}(189)=2,385, \mathrm{p}<.05)$ and enjoyment $(\mathrm{t}(189)=$ $-2,548, \mathrm{p}<.05)$ according to gender however, there was no significant difference according to gender in game passion $(\mathrm{t}(189)=-1,230, \mathrm{p}>.05)$. According to these findings;

There is no significant difference between men $(X=2,4154)$ and women $(X=2,5899)$ in game passion. In risk taking, males $(X=3,4313)$ have a more positive attitude than females $(\mathrm{X}=3,0000)$. In social cohesion, males $(X=4,2917)$ have a lower score than females $(X=$ $4,4603)$. In the game desire, males $(X=4,2676)$ are more willing than females $(X=4,0040)$. Females $(X=4,0040)$ enjoy games more than males $(\mathrm{X}=3,6934)$. However, considering the general average of the scale, it is seen that there is no significant difference between males $(\mathrm{X}=$ $3,5697)$ and females $(X=3,5733)$.

Table 4 shows the t-test findings for independent samples of participants' attitudes towards game play according to the disability situation.
When the findings on the game attitude scores of the participants were examined according to the disability situation, it was determined that there was a significant difference in the attitudes of the congenital disability individuals and those who became handicapped afterward $(\mathrm{t}(189)=-4.410, \mathrm{p}<.05)$.

When looked at the sub-factors of the attitudes towards playing games, it was found that there is no score difference in social cohesion ( $\mathrm{t}(189)=-1,859, \mathrm{p}>.05)$; on the other hand, significant differences were found in the game passion $(\mathrm{t}(189)=-2,998, \mathrm{p}<.05)$, risk taking $(\mathrm{t}(189)$ $=-2,649, \mathrm{p}<.05)$, game desiring $(\mathrm{t}(189)=-2,950, \mathrm{p}<.05)$ and enjoyment $(\mathrm{t}(189)=-3,961, \mathrm{p}<.05)$ between congenital disability individuals and those who became handicapped afterward.

According to these findings; It was determined that there was no difference between the individuals with born disability in social cohesion ( $X=4,3171)$ and afterward ( $X$ $=4,5309)$. It was determined that the scores of the individuals with born disability were higher than the people with disability afterward in the game passion, risk taking, game desire and enjoyment sub-factors. In other words, individuals with afterwards disability in these four sub-factors have a more positive attitude than those with congenital disabilities.

Table 4. Findings on Scores of Participants' the Attitudes towards Playing the Games According To Disability Status

\begin{tabular}{|c|c|c|c|c|c|c|c|}
\hline & Disability Status & $\mathbf{N}$ & Average & Std D. & $\mathbf{t}$ & Std D. & $\mathbf{p}$ \\
\hline \multirow{2}{*}{ Game Passion } & Congenital & 164 & 2,3933 & ,90798 & $-2,998$ & 189 &, 003 \\
\hline & Afterward & 27 & 2,9568 &, 88626 & & & \\
\hline \multirow{2}{*}{ Risk Taking } & Congenital & 164 & 3,2122 & ,98072 & $-2,649$ & 189 & ,009 \\
\hline & Afterward & 27 & 3,7556 & 1,03081 & & & \\
\hline \multirow{2}{*}{ Social Cohesion } & Congenital & 164 & 4,3171 & ,56337 & $-1,859$ & 189 &, 065 \\
\hline & Afterward & 27 & 4,5309 & ,48928 & & & \\
\hline \multirow{2}{*}{ Game desire } & Congenital & 164 & 4,1189 &, 73864 & $-2,950$ & 189 & ,004 \\
\hline & Afterward & 27 & 4,5556 &, 52042 & & & \\
\hline \multirow{2}{*}{ Enjoyment } & Congenital & 164 & 3,7058 &, 78470 & $-3,961$ & 189 &, 000 \\
\hline & Afterward & 27 & 4,3426 &, 70420 & & & \\
\hline \multirow{2}{*}{ Average } & Congenital & 164 & 3,5049 &, 51285 & $-4,410$ & 189 &, 000 \\
\hline & Afterward & 27 & 3,9719 & ,49063 & & & \\
\hline
\end{tabular}


Table 5. Findings on Scores of Participants' Attitude towards Game According to Sports Branches

\begin{tabular}{|c|c|c|c|c|c|c|c|}
\hline & Sports Branches & $\mathbf{N}$ & Average & Std. D. & $\mathbf{t}$ & Std. D. & $\mathbf{p}$ \\
\hline \multirow{2}{*}{ Game Passion } & Individual Sports & 145 & 2,3736 & ,94184 & $-2,682$ & 189 &, 008 \\
\hline & Team Sports & 46 & 2,7862 &, 79556 & & & \\
\hline \multirow{2}{*}{ Risk Taking } & Individual Sports & 145 & 3,2897 & 1,03089 & ,016 & 189 & ,987 \\
\hline & Team Sports & 46 & 3,2870 & ,92150 & & & \\
\hline \multirow{2}{*}{$\begin{array}{l}\text { Social } \\
\text { Cohesion }\end{array}$} & Individual Sports & 145 & 4,3103 &, 53490 & $-1,634$ & 189 & ,104 \\
\hline & Team Sports & 46 & 4,4638 & ,61455 & & & \\
\hline \multirow{2}{*}{ Game Desire } & Individual Sports & 145 & 4,2638 & ,64937 & 2,860 & 189 &, 005 \\
\hline & Team Sports & 46 & 3,9185 & ,88828 & & & \\
\hline \multirow{2}{*}{ Enjoyment } & Individual Sports & 145 & 3,7397 & ,85639 & $-1,724$ & 189 & ,086 \\
\hline & Team Sports & 46 & 3,9728 & ,58030 & & & \\
\hline \multirow{2}{*}{ Average } & Individual Sports & 145 & 3,5426 & ,52969 & $-1,301$ & 189 & ,195 \\
\hline & Team Sports & 46 & 3,6600 & ,54368 & & & \\
\hline
\end{tabular}

Table 5 shows the t-test findings for the independent samples of participants' attitudes towards playing games according to the sports branch.

When the findings on the game attitude scores of the participants were examined according to the sports branches, it was stated that there is no significant difference between handicapped individuals' game scores who are doing individual and team sports $(\mathrm{t}(189)=-1,301, \mathrm{p}>.05)$. Considering the sub-factors of game scores, it was found that there is a significant difference in the game passion $(\mathrm{t}$ $(189)=-2,682, p<.05)$ and game desire $(t(189)=2,860, p$ $<.05)$ according to sports branches; it was stated that there is no significant difference in sub-factors of risk taking $(\mathrm{t}$ $(189)=, 016, p>.05)$, social cohesion $(t)(189)=-1,634$, $\mathrm{p}>.05)$ and enjoyment $(\mathrm{t}(189)=-1,724, \mathrm{p}>.05)$.

According to these findings; in the game passion, those who make team sports $(\mathrm{x}=2,7862)$ are more positive than the ones who make individual sports $(x=2,3736)$; in terms of game desire, individual sports doers $(x=4,2638)$ have better attitude than those doing team sports $(x=3,9185)$. In risk taking, social cohesion and enjoyment sub-factors, there is no difference in the attitudes of the individual sports doers and those doing team sports.
Table 6 shows the t-test findings for the independent samples of the attitudes of the participants to play according to their marital status.

When the findings on scores of participants' attitudes towards game according to the marital status, it was determined that there was a significant difference in the game scores of the married and single handicapped individuals $(\mathrm{t}(189)=-2,980, \mathrm{p}<.05)$. When the sub-factors of game scores are considered, it is found that there is difference in sub-factors of risk taking $(\mathrm{t}(189)=-3,346, \mathrm{p}$ $<.05)$, game desire $(\mathrm{t}(189)=-2,450, \mathrm{p}<.05)$ and enjoyment ( $\mathrm{t}(189)=-3,896, \mathrm{p}<.05)$; it is found that there is no significant difference in sub-factors of game passion $(\mathrm{t}$ $(189)=-, 648, \mathrm{p}>.05)$ and social adaptation $(\mathrm{t}(189)=, 020$, $\mathrm{p}>.05)$.

According to these findings; those who are married $(\mathrm{X}=$ $3,72)$ have a better playing attitude than single ones $(\mathrm{X}=$ $3,4898)$. In the sub-factors of risk taking, game desire and enjoyment, those who are married, have a more positive attitude than single ones, and there is no difference between the attitudes of married and single individuals in game passion and social cohesion. 
Table 6. Findings on Scores of Participants' Attitude towards Game According to Marital Status

\begin{tabular}{|c|c|c|c|c|c|c|c|}
\hline & Marital Status & $\mathbf{N}$ & Average & Std. D. & $\mathbf{T}$ & Std. D. & $\mathbf{p}$ \\
\hline \multirow[t]{2}{*}{ Game Passion } & Single & 126 & 2,4418 & ,97121 &,- 648 & 189 & ,518 \\
\hline & Married & 65 & 2,5333 &, 82821 & & & \\
\hline \multirow[t]{2}{*}{ Risk Taking } & Single & 126 & 3,1190 & ,90445 & $-3,346$ & 189 &, 001 \\
\hline & Married & 65 & 3,6185 & 1,10608 & & & \\
\hline \multirow[t]{2}{*}{ Social Cohesion } & Single & 126 & 4,3479 &, 54448 & 020 & 189 & ,984 \\
\hline & Married & 65 & 4,3462 &, 58579 & & & \\
\hline \multirow[t]{2}{*}{ Game Desire } & Single & 126 & 4,0893 & ,67488 & $-2,450$ & 189 &, 015 \\
\hline & Married & 65 & 4,3577 &, 79423 & & & \\
\hline \multirow[t]{2}{*}{ Enjoyment } & Single & 126 & 3,6389 &, 78775 & $-3,896$ & 189 &, 000 \\
\hline & Married & 65 & 4,1000 & ,74974 & & & \\
\hline \multirow[t]{2}{*}{ Average } & Single & 126 & 3,4898 &, 52344 & $-2,980$ & 189 & ,003 \\
\hline & Married & 65 & 3,7280 &, 52298 & & & \\
\hline
\end{tabular}

One-way analysis of variance (ANOVA) results of participants' game scores according to age groups is given in Table 7.

Table 7. Findings on Scores of Participants' Attitude towards Game According to Age Groups

\begin{tabular}{|c|c|c|c|c|c|c|}
\hline & & Sum of Squares & Std. D. & Average of Squares & $\mathrm{F}$ & $\mathrm{p}$ \\
\hline \multirow{3}{*}{ Game Passion } & Inter-Groups & 13,16 & 2 & 6,58 & 8,302 & 0 \\
\hline & Intragroup & 149,006 & 188 & 0,793 & & \\
\hline & Total & 162,166 & 190 & & & \\
\hline \multirow{3}{*}{ Risk Taking } & Inter-Groups & 41,612 & 2 & 20,806 & 26,141 & 0 \\
\hline & Intragroup & 149,634 & 188 & 0,796 & & \\
\hline & Total & 191,247 & 190 & & & \\
\hline \multirow{3}{*}{ Social Cohesion } & Inter-Groups & 1,481 & 2 & 0,74 & 2,419 & 0,092 \\
\hline & Intragroup & 57,538 & 188 & 0,306 & & \\
\hline & Total & 59,018 & 190 & & & \\
\hline \multirow{3}{*}{ Game Desire } & Inter-Groups & 0,265 & 2 & 0,133 & 0,249 & 0,78 \\
\hline & Intragroup & 100,128 & 188 & 0,533 & & \\
\hline & Total & 100,393 & 190 & & & \\
\hline \multirow{3}{*}{ Enjoyment } & Inter-Groups & 0,739 & 2 & 0,37 & 0,57 & 0,566 \\
\hline & Intragroup & 121,922 & 188 & 0,649 & & \\
\hline & Total & 122,662 & 190 & & & \\
\hline \multirow{3}{*}{ Average } & Inter-Groups & 4,21 & 2 & 2,105 & 7,918 & 0 \\
\hline & Intragroup & 49,976 & 188 & 0,266 & & \\
\hline & Total & 54,185 & 190 & & & \\
\hline
\end{tabular}


When one-way ANOVA results on game attitude scores according to age groups were examined, it was determined that there was a significant differentiation in the game attitudes of the participants in terms of age groups (F (2, $188)=7.918 \mathrm{p}<.05)$. When the sub-factors according to age groups were examined, it was found that there were differences in factors such as game passion $(\mathrm{F}(2,188)=$ $8.302 \mathrm{p}<.05)$ and risk-taking $(\mathrm{F}(2,188)=26,141 \mathrm{p}<.05)$ but in social cohesion $(\mathrm{F}(2,188)=2,419.05)$, game desire $(\mathrm{F}(2,188)=, 249 \mathrm{p}>.05)$ and enjoyment $(\mathrm{F}(2,188)=, 570$ $\mathrm{p}>.05)$ factors, there was not a difference according to age groups.

As a result of Post Hoc-tests conducted to determine between the groups which the difference occurred, it is found that there were differences in scores of game desire between under 18 years and 18-30 years; in risk taking scores between under 18 years old and 18-30 years; under 18 years old and over 30 years; $18-30$ years and over 30 years old. In other words, there are significant differences among all age groups.
The results of one-way analysis of variance (ANOVA) for game attitude scores according to the education level of the participants are given in Table 8 .

When one-way ANOVA results on game attitude scores according to education status were examined, it was found that there was no differentiation in participants' game scores in terms of education status $(\mathrm{F}(2,188)=2.641$ $\mathrm{p}>.05)$. When sub-factors according to education status were analyzed it was found that there was differentiation in game passion $(\mathrm{F}(2,188)=9,297 \mathrm{p}<.05)$ and risk taking factors $(F(2,188)=3,494 p<.05)$. However, it was stated that there was no significant difference in social cohesion $(\mathrm{F}(2,188)=, 085 \mathrm{p}>.05)$, game desire $(\mathrm{F}(2,188)=, 610$ $\mathrm{p}>.05)$, and enjoyment factors $(\mathrm{F}(2,188)=1,965 \mathrm{p}>.05)$.

As a result of Post-Hoc test which was conducted to determine in which groups that the differentiation occurred in these sub-factors; it was found that there were differentiations in game passion scores between high school and university graduates; in risk taking scores between primary school and high school graduates.

Table 8. Findings on Scores of Participants' The Attitudes towards Playing The Games According To Education Status

\begin{tabular}{|c|c|c|c|c|c|c|}
\hline & & Sum of Squares & Std. D. & Average of Squares & $\mathbf{F}$ & $\mathbf{p}$ \\
\hline \multirow{3}{*}{ Game Passion } & Inter-Groups & 14,595 & 2 & 7,297 & 9,297 & 0 \\
\hline & Intragroup & 147,571 & 188 & 0,785 & & \\
\hline & Total & 162,166 & 190 & & & \\
\hline \multirow{3}{*}{ Risk Taking } & Inter-Groups & 6,854 & 2 & 3,427 & 3,494 & 0,032 \\
\hline & Intragroup & 184,393 & 188 & 0,981 & & \\
\hline & Total & 191,247 & 190 & & & \\
\hline \multirow{3}{*}{ Social Cohesion } & Inter-Groups & 0,053 & 2 & 0,027 & 0,085 & 0,919 \\
\hline & Intragroup & 58,965 & 188 & 0,314 & & \\
\hline & Total & 59,018 & 190 & & & \\
\hline \multirow{3}{*}{ Game Desire } & Inter-Groups & 0,647 & 2 & 0,323 & 0,61 & 0,545 \\
\hline & Intragroup & 99,746 & 188 & 0,531 & & \\
\hline & Total & 100,393 & 190 & & & \\
\hline \multirow{3}{*}{ Enjoyment } & Inter-Groups & 2,512 & 2 & 1,256 & 1,965 & 0,143 \\
\hline & Intragroup & 120,15 & 188 & 0,639 & & \\
\hline & Total & 122,662 & 190 & & & \\
\hline \multirow{3}{*}{ Average } & Inter-Groups & 1,481 & 2 & 0,74 & 2,641 & 0,074 \\
\hline & Intragroup & 52,705 & 188 & 0,28 & & \\
\hline & Total & 54,185 & 190 & & & \\
\hline
\end{tabular}


Table 9. Findings on Scores of Game Attitude According to Income Level

\begin{tabular}{|c|c|c|c|c|c|c|}
\hline & & Sum of Squares & Std. D. & Average of Squares & $\mathbf{F}$ & $\mathbf{p}$ \\
\hline \multirow{3}{*}{ Game Passion } & Inter-Groups & 14,237 & 2 & 7,119 & 9,047 &, 000 \\
\hline & Intragroup & 147,928 & 188 &, 787 & & \\
\hline & Total & 162,166 & 190 & & & \\
\hline \multirow{3}{*}{ Risk Taking } & Inter-Groups & 14,395 & 2 & 7,198 & 7,651 &, 001 \\
\hline & Intragroup & 176,852 & 188 & ,941 & & \\
\hline & Total & 191,247 & 190 & & & \\
\hline \multirow{3}{*}{ Social Cohesion } & Inter-Groups & 5,077 & 2 & 2,538 & 8,847 &, 000 \\
\hline & Intragroup & 53,942 & 188 & ,287 & & \\
\hline & Total & 59,018 & 190 & & & \\
\hline \multirow{3}{*}{ Game Desire } & Inter-Groups & 20,085 & 2 & 10,042 & 23,509 &, 000 \\
\hline & Intragroup & 80,309 & 188 & ,427 & & \\
\hline & Total & 100,393 & 190 & & & \\
\hline \multirow{3}{*}{ Enjoyment } & Inter-Groups & 3,433 & 2 & 1,717 & 2,707 &, 069 \\
\hline & Intragroup & 119,229 & 188 & ,634 & & \\
\hline & Total & 122,662 & 190 & & & \\
\hline \multirow{3}{*}{ Average } & Inter-Groups & 3,337 & 2 & 1,668 & 6,168 &, 003 \\
\hline & Intragroup & 50,849 & 188 &, 270 & & \\
\hline & Total & 54,185 & 190 & & & \\
\hline
\end{tabular}

The results of one-way analysis of variance (ANOVA) for game attitude scores according to the education level of the participants are given in Table 9.

When one-way ANOVA results on game attitude scores according to income level were examined, it was found that there was significant differentiation in participants' game scores in terms of income level $(\mathrm{F}(2,188)=6,168 \mathrm{p}<.05)$. Again when sub-factors according to income level were analyzed, it was found that there was significant differentiation in scores of game passion $(\mathrm{F}(2,188)=$ $9,047 \mathrm{p}<.05)$, risk taking $(\mathrm{F}(2,188)=7,651 \mathrm{p}<.05)$, social cohesion $(\mathrm{F}(2,188)=8,847 \mathrm{p}<.05)$ and game desire $(F(2,188)=23,509 p<.05)$. It was found that there was no difference in enjoyment factor $(\mathrm{F}(2,188)=2,707$ $\mathrm{p}>.05$ ) according to income level.

As a result of Post-Hoc test which was conducted to determine in which groups that the differentiation occurred in these sub-factors; it was found that there were differences between 1000 and 3000, 1000-2000 and 3000 in general average of the game attitudes. In sub-factors; it was found in game passion that between 1000 and
1000-2000; 1000-2000 and 3000; in risk taking 1000 and 1000-2000; in social cohesion 1000 and 1000-2000, and 1000-2000 and 3000; in game desire 1000 and 3000 and $1000-2000$ and 3000 .

When one-way ANOVA results on game attitude scores according to visual acuity were examined, it was found that there was significant differentiation in participants' game scores in terms of visual acuity $(\mathrm{F}(2,188)=2,997 \mathrm{p}>.05)$. Again when sub-factors were analyzed according to visual acuity, it was found that there was significant difference in social cohesion $(\mathrm{F}(2,188)=3,102 \mathrm{p}<.05)$ and game desire $(F(2,188)=12,765 \mathrm{p}<.05)$ according to visual acuity. It was found that there was no difference in game passion $(\mathrm{F}(2,188)=, 677 \mathrm{p}>.05)$, risk taking $(\mathrm{F}(2,188)=$ $2,306 \mathrm{p}>.05)$ and enjoyment factors $(\mathrm{F}(2,188)=, 877$ $\mathrm{p}>.05$ ) according to visual acuity.

As a result of Post-Hoc test which was conducted to determine in which groups that the differentiation occurred in these sub-factors; it was found that there were differences between $\mathrm{B} 2$ and $\mathrm{B} 3$ in social cohesion; between $\mathrm{B} 1$ and $\mathrm{B} 2$ in game desire, and $\mathrm{B} 2$ and $\mathrm{B} 3$. 
Table 10. Findings on Scores of Game Attitude According to Visual Acuity

\begin{tabular}{|c|c|c|c|c|c|c|}
\hline & & Sum of Squares & Std. D. & Average of Squares & $\mathbf{F}$ & $\mathbf{p}$ \\
\hline \multirow{3}{*}{ Game Passion } & Inter-Groups & 1,16 & 2 & 0,58 & 0,677 & 0,509 \\
\hline & Intragroup & 161,006 & 188 & 0,856 & & \\
\hline & Total & 162,166 & 190 & & & \\
\hline \multirow{3}{*}{ Risk Taking } & Inter-Groups & 4,58 & 2 & 2,29 & 2,306 & 0,102 \\
\hline & Intragroup & 186,667 & 188 & 0,993 & & \\
\hline & Total & 191,247 & 190 & & & \\
\hline \multirow{3}{*}{ Social Cohesion } & Inter-Groups & 1,885 & 2 & 0,943 & 3,102 & 0,047 \\
\hline & Intragroup & 57,133 & 188 & 0,304 & & \\
\hline & Total & 59,018 & 190 & & & \\
\hline \multirow{3}{*}{ Game Desire } & Inter-Groups & 12,003 & 2 & 6,002 & 12,765 & 0 \\
\hline & Intragroup & 88,39 & 188 & 0,47 & & \\
\hline & Total & 100,393 & 190 & & & \\
\hline \multirow{3}{*}{ Enjoyment } & Inter-Groups & 1,133 & 2 & 0,567 & 0,877 & 0,418 \\
\hline & Intragroup & 121,528 & 188 & 0,646 & & \\
\hline & Total & 122,662 & 190 & & & \\
\hline \multirow{3}{*}{ Average } & Inter-Groups & 1,674 & 2 & 0,837 & 2,997 & 0,052 \\
\hline & Intragroup & 52,511 & 188 & 0,279 & & \\
\hline & Total & 54,185 & 190 & & & \\
\hline
\end{tabular}

\section{Discussion - Result}

A total of 191 visual impairment individuals, including 63 females and 128 males, participated in this study which is conducted with the aim of determining their attributes towards playing games containing physical activity.

When the findings of the attitude points of the visually handicapped participants towards play according to gender are examined, it is found that there is no significant difference in participants' game scores according to gender $(p>0.05)$. When looked at the sub-factors of their attitudes towards playing games; it was found that there was a significant difference according to gender in risk-taking ( $\mathrm{p}$ $<0.05)$, social cohesion $(\mathrm{p}<0.05)$, play desire $(\mathrm{p}<0.05)$ and enjoyment $(p<0.05)$ sub-factors; there was no significant difference in $(p>0.05)$ according to gender. In his study, on the students' their attitudes towards playing games with physical activity, in the departments of coaching and sports management in according to the gender, when game passion, risk-taking, social cohesion, enjoyment and game desires' general averages, Öztürk (2016) found that there was no significant difference. Genç et al. (2011), in the study of determining the differences between the physical activity and quality of life among male and female young adults, found that male and female adults had higher scores than males. Leslie et al. (1999) found that the physical activity levels of male students were higher than female students according to the results of their study on university students. Males take a more positive attitude than females in risk-taking. In social cohesion, males have had a lower score than females. In game desire, males are more willing to play than females. Females enjoy games more than males. However, when we look at the general average of the scale, it is found that there is no significant difference between men and women. Similar studies support our study.

When the findings of the attitude points of the visually handicapped participants towards play according to sports branches are examined, it is found that there is no significant difference in participants' game scores according to sports branches ( $>0.05)$. Considering the sub-factors of game scores according to sports branches; it was found that there was a significant difference in game passion $(p<0.05)$ and game desire $(p<0.05)$ scores according to sports branches; no significant difference was found in risk-taking $(p>0.05)$, social cohesion ( $p>0.05)$ and enjoyment $(p>0.05)$. According to these findings; team sports doers have a better attitude than individual sports doers in-game passion and individual sports doers have a better attitude than team sports doers in-game desire. In risk-taking, social cohesion and enjoyment sub-factors, there is no difference in the attitudes of the individual and team sports doers. Sports enables individuals with disabilities to do their work independently, to follow his nose, to be optimistic and more tolerant, to enjoy life and struggle, to encourage others and themselves, to participate in all aspects of life, to choose righteousness and transparency in their communication, to be intertwined with people, to gain positive personality traits such as being able to accept and coping with disabilities, not being 
isolated from society, owning their problems, feelings, ambitions and intuitions, to be tolerant to the environment, to trust and valuing them, and to make people feel that individuals with disabilities gain places in society. The authors who evaluate the benefits of participating in physical activities with disabilities in the philosophical sense, as a result of emphasis their contribution to emotional development and psychomotor development (Hazar, 1996), state that sports are critical to handicapped individuals. Studies have shown that sports and play have an important place in the development of children and contribute to their healthier growth (Hazar, 1996). The game opens a wider path for people with disabilities. Besides physical education and sports activities enable individuals with disabilities to control their feelings such as aggression, anger, and jealousy as a natural result of their moods and the attitude of the society towards themselves (Kınal1, 2003), they have an important role in empathy, self-efficacy, motivation, and sense of achievement. We can say that the visual impairment individuals are in the sports branches and that they can do sports and prove themselves in the Paralympic games. Their feelings and thoughts are the same and the expectations from the game in the sports branch are the same, no matter what their sports branches are. Since similar studies were not conducted, no findings were found to support our study.

When the findings of the attitude points of the visually handicapped participants towards play according to marital status are examined, it is found that there is a significant difference in single participants' game scores according to marital status $(p<0.05)$. When the sub-factors of the game scores were examined, it was found that there was a difference in the risk-taking $(\mathrm{p}<0.05)$, game desire $(\mathrm{p}$ $<0.05)$ and enjoyment $(p<0.05)$; it was found that there is no significant difference in sub-factors of game passion $(p>0.05)$ and social cohesion ( $>0.05)$. According to these findings, married ones have better attitudes than single ones. The married individuals have better attitudes than single ones in sub-factors of risk-taking, game desire, and enjoyment; it is found that there is no significant difference between married ones and single ones in game passion and social cohesion. We think that the difference in visual impairment individuals' attitudes towards playing is resulted from being married or single. It can be said that individuals' being married, family order, affect their attitudes towards playing games. As there is no literature or different studies on this, there are no conclusions to support our study.

When one-way ANOVA results related to playing attitude scores according to age groups were examined, it was found that there was a significant difference in the game attitudes of the participants in terms of age groups ( $p$ $<0.05$ ). Again when the sub-factors were examined according to age groups, it was found that there was a difference in game passion $(\mathrm{p}<0.05)$ and risk-taking ( $p$ $<0.05$ ) factors; but in social cohesion ( $>0.05)$, play desire
( $>>0.05)$ and enjoyment ( $>0.05)$ factors, It was determined that there was no difference according to age groups. As a result of Post Hoc tests, which was conducted to determine in which groups the differentiation occurred between these two sub-factors; it was stated that there were differences between the ages of under 18 years and 30 in-game passion; under 18 years old and 18-30 years; under 18 years and over 30 years; $18-30$ years and over 30 years in risk-taking. In other words, there is a significant difference among all age groups in risk-taking scores. In his study, on the students' their attitudes towards playing games with physical activity, in the departments of coaching and sports management in according to the gender, when game passion, risk-taking, social cohesion, enjoyment and game desires' general averages, Öztürk (2016) found that there was no significant difference. In a study performed by Kalkavan et al. (1996), a statistically significant difference was found on physical fitness between 108 young people in different branches of the age group of 12-15 years and 19 sedentary young people in the result of 58 variables' comparison. Riddoch and Boreham (2004), in a study on 2185 children aged 9-15 years, it was found that there was found a significant difference between the participation in the activity the total activity level of 9 and 15 -year-old children. When we look at the literature, it is possible to reach similar and different results.

When one-way ANOVA results on game attitude scores were examined according to educational status, it was determined that there was no significant difference in the game scores of the participants in terms of educational status ( $p>0.05)$. When the sub-factors were examined according to age groups, it was found that there was a difference in game passion $(\mathrm{p}<0.05)$ and risk-taking ( $\mathrm{p}$ $<0.05$ ) factors; but in social cohesion ( $p>0.05$ ), play desire ( $>>0.05)$ and enjoyment ( $>0.05)$ factors, It was determined that there was no difference according to education status. As a result of Post Hoc tests which was conducted to determine in which groups the differentiation occurred between these two sub-factors; it was stated that there were differences in game passion sub-factor between high school and university graduates and between primary school and high school graduates in risk-taking scores. The reason why the game differs according to the level of education can be grounded on the fact that the game does not have a significant relationship with the education status. We can say that the reason why some of the items are different has resulted from the differences in some items of the subscales. When looked at the scale; we emphasize that the education status is different due to the fact that the level of education on the game is not effective and that the handicapped individuals have similar expectations from the game. Since similar studies were not conducted, the findings to support our study were not found.

When one-way ANOVA results on game attitude scores were examined according to the level of income, it was determined that there was no significant difference in the 
game scores of the participants in terms of the level of income $(p>0.05)$. When the sub-factors were examined according to level of income, it was found that there was a difference in game passion $(\mathrm{p}<0.05)$ and risk-taking $(\mathrm{p}$ $<0.05)$, social cohesion $(\mathrm{p}>0.05)$, play desire $(\mathrm{p}>0.05)$ sub-factors; but in enjoyment $(p>0.05)$ factor, it was determined that there was no difference according to level of income. As a result of Post Hoc tests which was conducted to determine in which groups the differentiation occurred between these two sub-factors; it was stated that there were differences between 1000 and 3000; and 1000-2000 and 3000 in general average of game attitudes. In sub-factors; it was stated that there was a significant difference between 1000 and 1000-2000, and 1000-2000 and 3000 in game passion; between 1000 and 1000-2000 in risk-taking; between 1000-1000-2000, and 1000-2000 and 3000 in social cohesion; between 1000 and 3000, 1000-2000 and 3000 in game desire. As seen, we see that the level of income is important in the game. We can say that the difference in the level of income, and the expectations of the individuals change according to the materiality. When we look at the total scores and sub-dimensions taken from the scale as a result of the effect of the materiality on handicapped individuals, we see a significant difference. Since similar studies were not conducted, the findings to support this idea could not be reached.

When the findings on the game attitude scores of the participants were examined according to the disability situation, it was determined that there was a significant difference in the attitudes of the individuals with congenital and afterward disability $(\mathrm{p}<0.05)$. When we look at the sub-factors of the attitudes towards playing games, it was found that there was no difference in social cohesion $(p>$ $0.05)$ scores, on the other hand there was a significant difference in game passion $(p<0.05)$, risk-taking $(p<0.05)$, game desire $(\mathrm{p}<0.05)$ and enjoyment $(\mathrm{p}<0.05)$ sub-factors between individuals with congenital and afterward disability. According to these findings; it was found that there was no difference between the individuals with congenital and afterward disability. In the sub-factors of game passion, risk-taking, game desire, and enjoyment, it was determined that the scores of individuals with afterward disability were higher than those people with congenital disability. In other words, individuals with afterward disabilities in these four sub-factors have a more positive attitude than those with congenital disabilities. We can say that visual impairment individuals' attitudes towards being different may have resulted from their congenital or afterward disabilities. As a result of the individual being born with a disability; it is observed that the expectations from the game are different and that their expectations are shaped accordingly. Since similar studies were not conducted, the findings to support this idea could not be reached.

When the findings on the game attitude scores of the participants were examined according to visual acuity, it was determined that there was not a significant difference in participants' visual acuity $(p>0.05)$. When we look at the sub-factors of the attitudes towards playing games according to visual acuity, it was found that there was a significant difference in social cohesion $(p>0.05)$, game desire $(p<0.05)$ scores; on the other hand there was not a significant difference in game passion ( $p>0.05)$, risk-taking $(\mathrm{p}>0.05)$, and enjoyment $(\mathrm{p}<0.05)$ sub-factors. As a result of Post Hoc tests which was conducted to determine in which groups the differentiation occurred between these two sub-factors; it was stated that there were differences between B2 and B3 in social cohesion; between $\mathrm{B} 1$ and B2, and B2 and B3 in game desire. It is found that the visual impairment individuals' expectations from the game according to the visual acuity are similar, but some items of the scale were found to be different. We think that their visual acuity levels' being different may be resulted from their expectations from the game. It is extremely important that vision is a vital organ that allows people to understand what is going on outside the world. If the degree of humanity is different, we can say that the expectations are different. In the literature, similar or different results have not been reached for the study of individuals with disabilities as no study was conducted.

According to the results of this study, it is determined that the game is to what extent effective against individuals with disabilities. In fact; it was observed that in the game, handicapped individuals were able to use their feelings more widely and to control their behaviors at a high level. The most important of these findings is that the game affects the visual impairment individuals to a great extent. It is very important for individuals to develop their skills, feelings, and thoughts while creating attitudes of visual impairment individuals towards the game. It should be ensured that the game is located in every corner of the life of the handicapped individuals. Game training should be provided through training. The game, the attitudes of visual impairment individuals towards playing games containing physical activity, should not be considered as a recreating activity played by visual impairment individuals. It should not go unnoticed that the game is a real and important tool in human life. The game develops the imagination, creativity, body, and psychology of both children and individuals; enhances human relations, socialization, cooperation and enjoyment of life and many of the rules that are hardly taught and which should be obeyed can be taught more easily to individuals during play. In short, the game is the easiest way for people with disabilities to be a part of their lives and can freely express themselves, do something during the game, voluntarily play in games, enjoy them, and prove their existence by adhering to rules and events. By forgetting the concept of the disability, enjoying the game, eliminating the stress and the distress of life, it is a piece of those people to hold on to the life. 


\section{REFERENCES}

[1] Açak M, Ilgın A, Erhan S. (1997). Beden eğitimi öğretmeninin el kitabı, Malatya: Dünya Ambalaj San. Tic.

[2] Akdenk, M, Ağaoğlu, S.A., İmamoğlu, O. (1997). Türkiye'de Engelliler İçin Uygulamalı Spor Eğitimi Modeli, Antalya Uluslararası Engellilerde Spor Eğitim Sempozyumu, (179-191), Antalya.

[3] Akı, E., \& Kayıhan, H. (2003). Az Gören Çocuklarda Görsel Algılama Eğitiminin Yazma, Okuma ve Günlük Yaşam Aktivitelerine Etkisi. Fizyoter Rehabil, 14(3), 95-99.

[4] Alpar. R. (2010). Uygulamalı İstatistik ve Geçerlik-Güvenirlik. Detay Yayıncılık, s. 350, Ankara.

[5] Atay, M. (1995) Engelli Bireylerde Benlik Gelişiminde Spor Etkinliklerinin Önemi, Uluslararası Engellilerde Spor Eğitimi Sempozyumu, G.S.G.M. Spor Eğitimi Daire Başkanlığı, Yayın No: 1997/1, Antalya

[6] Barnes, C. (1998).The social model of disability: A sociological phenomenon ignored by sociologists. In $\mathrm{T}$. Shakespeare (Ed.), the disability studies reader (pp. 65-78). London: Cassell.

[7] Çoban, B. (2006). Ortaöğretimde ve üniversitelerde eğitsel oyunlar. Nobel Yayıncılık, 237s, Ankara.

[8] Dalbudak, İ. (2012). 13-15 Yaş Arası Görme Engelli Sporcuların Stres ve Saldırganlık Düzeylerinin İncelenmesi, Ege Üniversitesi, Sağlık Bilimler Enstitüsü, Sporda Psiko-Sosyal Alanlar Anabilim Dalı, Yayımlanmış Yüksek Lisans Tezi, S.103-104. İzmir.

[9] Erdem, Ö. (2003). Okul öncesi eğitim birimlerinde dış mekân tasarım ilkeleri. Yayınlanmamış Yüksek Lisans Tezi, Ankara Üniversitesi Fen Bilimleri Enstitüsü Peyzaj Mimarlığı, Ankara.

[10] Ergun, N., Algun, C., Dolunay, N. (1990). Engellilerde Spor Yaklaşımı, Spor Şurası Bildirileri, Gençlik ve Spor Genel Müdürlüğü Yayınları, Ankara.

[11] Genç, A., Şener, Ü., Karabacak, H., Üçok, K. (2011). Investigation of Physical Activity and Quality of Life Differences between Male and Female Young Adults. The Medical Journal of Kocatepe, 12, 145-150.

[12] Georges, R. (2007). Eğlence ve Oyunlar. Milli Folklor Dergisi. Say1: 74

[13] Hargreaves, J. (2000). Heroines of sport: The politics of difference and identity. London: Routledge.

[14] Hazar. M. (2013). "Üniversite Öğrencilerinin Fiziksel Aktivite İçeren Oyunları Oynamaya Yönelik Tutum Ölçeği (Oyunsallık Ölçeği)", Niğde Üniversitesi Beden Eğitimi ve Spor Bilimleri Dergisi. Vol.8, No. 1.

[15] Hazar. M. (2015). 18-22 Yaş Yetişkinlerin Fiziksel Aktivite İçeren Oyunları Oynamaya Yönelik Tutumları (18-22 Yaş Oyunsallık Ölçeğinin Geliştirilmesi). Niğde Üniversitesi Beden Eğitimi Ve Spor Bilimleri Dergisi. Vol. 9, No. 1.

[16] Hazar, M. (2000). Beden Eğitimi ve Sporda Oyunla Eğitim.
Saray Matbaası, s.4, Ankara.

[17] Hazar M. (1996). Beden Eğitimi ve Sporda Oyunla Eğitimi. Ankara.

[18] Huizinga, J. Homo Ludens. (2006). Oyunun Toplumsal İşlevi Üzerine Bir Deneme. (Çeviren, M. A. Kılıçbay.). Ayrıntı Yayınları, s.50, İstanbul.

[19] IBSA. (2006). Capable of Everything. International Blind Sports Federation, Madrid, Spain, s.35 -37-59.

[20] Kalkavan A, Zorba E, Ağaoğlu SA, Karakuş S, Çolak H. Farklı spor branşlarında bazı fiziksel uygunluk değerlerinin sedanter grupla karşılaştırılması, Gazi Üniversitesi Beden Eğitimi ve Spor Bilimleri Dergisi, 1996; 1(3): 25-35.

[21] Kayri, M. (2009). Araştırmalarda Gruplar Arası Farkın Belirlenmesine Yönelik Çoklu Karşılaştırma (Post-Hoc) Teknikleri, Firat Üniversitesi Sosyal Bilimler Dergisi, Firat University Journal of Social Science Cilt: 19, Say1: 1, Sayfa: 51-64, Elazığg.

[22] Kınalı, G. (2003). Zihin Engellilerde Beden - Resim -Müzik Eğitimi, Farklı Gelişen Çocuklar, (Ed: Kulaksızoğlu A.), Epsilon Yayınları, İstanbul.

[23] Leslie, E., Owen, N., Salmon, J., Bauman, A., Sallis, J.F., Lo, S.K. (1999). Insufficiently Active Australian College Students: Perceived Personal, Social, and Environmental İnfluences. Preventive Medicine, 28, 20-27.

[24] Saracho, O. N. (2004). Supporting literacy-related play: roles for teachers of young children. Early Childhood Educational Journal, 31(3), 201-206.

[25] Şahin, T. F. (1993). Üç - Altı Yaş Grubu Çocuklarının Anne ve Babalarının Çocuk Oyun ve Oyuncakları Hakkındaki Görüşlerinin İncelenmesi. Çocuk Sağlığı ve Eğitimi Programı Bilim Uzmanlığı Tezi, Sağlık Bilimleri Enstitüsü, T.C. Hacettepe Üniversitesi, Ankara.

[26] Turnbull, H.R., Turnbull, A., Shank, M., Smith, S.J. (2004). Exceptional Lives Special Education in Today's Schools. Pearson Press, Boston

[27] Özer, D. (2001). Engelliler İçin Beden Eğitimi ve Spor, Nobel Yayın Dağıtım, S.1-89, Ankara,

[28] Özoğlu, S.C. (1997). Spor Psikolojisi ve Gelişmeler, I. Uluslararası Spor Psikolojisi Sempozyumu, Bağırgan Yayınevi, Ankara.

[29] Öztürk, H. (2016). Attıtudes Of Students Studyıng In Coaching And Sport Management Department Towards Playing Games Involving Physical Actıvity, Gaziantep University Journal of Social Sciences, 15(2):717-728

[30] Özürlüler İdaresi Başkanlığı (ÖZİDA), Devlet İstatistik Enstitüsü Başkanlığı (2002). Türkiye Özürlüler Araştırması - Turkey Disability Survey. 21(4), Devlet İstatistik Enstitüsü, Ankara.

[31] Özürlüler İdaresi Başkanlığı (ÖZİDA), (1999). 1. Özürlüler Şuras1: Çağdas Toplum, Çağdaş Yaşam ve Özürlüler Komisyon Raporları ve Genel Kurul Görüşmeleri. T.C. Başbakanlık Özürlüler İdaresi Başkanlığı, Ankara.

[32] Özyürek, M. (1995). Görme Yetersizliği Olan Çocuğu Bağımsızlığa Hazırlamak İçin Ana-Baba Rehberi. Başbakanlık Aile Araştırma Kurumu Yayınları, Kasım, 
Ankara.

[33] Riddoch CJ, Boreham CA. The Health- Related Physical Activity of Children. Sports.” Med: 2004; 19(2): 86-102.

[34] Yaşar, Ö. (2019), Toplumsal Değişme ve Anaokulu İhtiyacı, Social Change and The Need For Nursery Schools, Turkish Studies - Educational Sciences, Volume 14, Issue 2, P. 855-872, Ankara.

[35] Yeşilkaya, İ. (2013). 7.sınıf sosyal bilgiler dersi "zaman içinde bilim "ünitesinin eğitsel oyun yöntemi ile öğretimi. Yüksek Lisans Tezi, Eğitim Bilimleri Enstitüsü, T.C. İnönü Üniversitesi, Malatya.

[36] World Healt Organization (WHO). 2013). Visual İmpairment and Blindness. http://www.who.int/ mediacentre/factsheets/fs282/en. 